\title{
Similarities and Differences of E-Commerce and e-Government: Insights from a Pilot Study
}

\author{
Karine Barzilai-Nahon and Hans J (Jochen) Scholl \\ The Information School, University of Washington \\ \{karineb,jscholl\}@u.washington.edu
}

\begin{abstract}
So far, empirically grounded studies, which compare the phenomena of e-Commerce and e-Government, have been in short supply. However, such studies it has been argued would most likely deepen the understanding of the sector-specific similarities and differences leading to potential cross-fertilization between the two sectors as well as to the establishment of performance measures and success criteria. This paper reports on the findings of an empirical research pilot, which is the first in a series of planned exploratory and theory-testing studies on the subject.
\end{abstract}

\section{Introduction}

E-Commerce and e-Business have been portrayed as private-sector siblings and antecedents of e-Government [1]. At face value, many transactional and informational phenomena observed in private-sector e-Commerce arenas seem to be mirrored in e-Government, and vice versa. Also, field-/front office work and back office work in both sectors have undergone major changes in the wake of introducing capabilities and methods, which exploit computer-mediated networks such as the Internet and the Web. Interestingly, few studies exist, if any, which capture lessons learned and summarize current practices, or establish measures across sector boundaries for success of this rapid socio-technical evolution ${ }^{1}$. The organizational and social impacts and consequences in the e-Commerce/e-Government evolution, however, may represent the far more challenging problems to understand than the admittedly non-trivial (technical) interplay of systems and networks.

This paper summarizes the findings of an empirical pilot on the subject, which surfaces several expected and some surprising differences and similarities of eCommerce and e-Government. The respective lessons learned, the current practices, and the metrics of success might benefit both sectors and both evolutionary paths.

\footnotetext{
${ }^{1}$ The International Journal of Electronic Business has published a special issue on "e-Government and e-Business as Complementary Innovations: Transferable Lessons and Diffusion Dynamics” (IJEB, vol 4, iss 2, 2004). However, the issue falls short of providing any systematic comparison or synopsis of the two phenomena.
}

Deeper understanding of the complex mesh of technological, organizational, and social factors and processes in both e-Commerce and e-Government might lead to practice-relevant cross-fertilization and reduction of unnecessary reduplication. This paper is organized as follows. First, we recap the distinction between the public and private sectors, both in general and in informationtechnology-related contexts. Second, we briefly review pertinent literature on e-Commerce and e-Government. Third, we introduce and discuss the study design followed by the presentation and discussion of our findings. We conclude by laying out the design and orientation of the subsequent studies in this research series.

\section{The Public-Private Distinction}

Traditionally, public-to-private differences have been identified in three areas: (1) environmental drivers and constraints, (2) organizational mandates and scope, and (3) internal processes, complexities, and incentives [2]. Among other distinguishing dimensions, the private sector has been praised for its higher agility, greater resourcefulness, less burdensome bureaucracy, and stronger motivation to proactively innovate when compared with public sector organizations [3-5, 2, 6]. However, as Perry and Rainey observed, in practice the distinction between the two sectors might be troublesome, since apart from the clear-cut cases of publicly owned, and publicly funded organizations versus privately owned, and privately funded firms, all shades of grey, that is, hybrids exist, which considerably blur the sector boundaries and make the distinction between public and private sector organizations less meaningful, if not even problematic at times [7]. We recognize that our initial comparison has to remain at a relatively high level of observation and analysis. More fine-grained sub-sectorspecific analysis might be found necessary.

\section{Sector Differences and Similarities as Seen by Traditional Information Systems (IS) Research}

In contrast to private Management Information Systems (MIS), which are mainly geared at increasing economic efficiency and profitability, their public counterparts (PMIS) had to simultaneously provide both economic and political efficiencies and also serve a policy 
mission [4]. Further, unlike private MIS, PMIS yielded only few labor savings. Finally, the (at times extreme) scarcity of skilled labor had been a chronic challenge for public IT managers and CIOs for decades (ibid).

To a certain extent, those differences might also hold when comparing e-Commerce with e-Government, and vice versa. In a recent study, public IS managers were found to pursue different priorities in their IT investments than their private colleagues: In rank order, the top five priorities for public-sector CIOs were (1) the implementation of an IT architecture, (2) cultural change, (3) hiring/retaining skilled professionals, (4) unifying/streamlining, and (5) simplifying business processes [8]. By contrast, private-sector CIOs ranked their priorities as (1) simplifying business processes, (2) improving service, (3) effective relationships with senior executives, (4) preventing intrusions, and (5) the implementation of IT architecture (ibid).

Although subjected to identical sector specifics, traditional PMIS and e-Government systems (EGIS) appear different in a number of ways [9]. Therefore, a detailed analysis of the characteristics of EGIS and eCommerce systems and applications appears necessary for developing deeper understanding.

\section{Recent e-Commerce and e-Government Literature Related to the Subject}

The most recent comprehensive literature review on electronic Commerce, which we were able to find, dates back from the year 2000 and covers literature published in the timeframe of 1993 through 1999 [10]. It revealed that the early literature on the subject fell into mainly three broad categories: (1) technology-related topics, (2) application-related topics (including inter- and intraorganizational systems), and (3) support and implementation-related topics (ibid). For e-Government research, any comprehensive review and classification of the literature is still missing (Grönlund's contributions are aimed at determining the scientific quality of eGovernment research rather than classifying the topical emphases [11, 12]). As a consequence, those reviews do not lend themselves to a sound basis for comparison. Further, we deliberately exclude a review of the literature of New Public Management (NPM). Opposed to a few scholars, practitioners, and politicians, we do not consider e-Government a fulfillment of NPM-based ideas, but rather an independent phenomenon with roots in all traditions of public administration.

Therefore in the following we portray the two bodies of literatures separately and link them as appropriate. Since 2000, however, the e-Commerce and the eGovernment-related streams of literature have independently reported on effects and outcomes, which indicate similarities, differences, as well as different emphases in the two sectors. Increased trust, risk and knowledge sharing, improved economies of scale and scope, shortened time to market, lower transaction cost, reduced information asymmetries, and improved coordination were found among the effects in the private sector as a consequence of the introduction of eCommerce [13, 14]. E-Government has reportedly led to business process change, process speedups, increased internal efficiency, improved information sharing and interoperation, greater transparency and accountability, greater proximity to citizens, and improved service levels among other effects [1, 15-18].

In the private sector, e-Commerce applications have been increasingly integrated with traditional information systems and their respective infrastructures in recent years [19]. In supply chains, for example, the management of sourcing (reverse auctioning), coordination, and electronic exchanges via e-Commerce applications had a strong influence on the improvement of operational performance of private-sector firms (ibid). Inter-organizational collaboration in e-Commerce has been facilitated through the alignment and interfacing of workflows and processes in a way, which preserves organizational autonomy [20]. Organizational transformation in terms of changing processes and business models was observed to be driven by eCommerce-based effects such as the immediacy of deliverability, higher information intensity, customizability, service bundling, cost reductions, risk containment, standards, and access to complementary services [21]. Other authors document the withering of information asymmetries between supply chain members as a consequence of ubiquitous Web-based information availability [22]. Although upon implementation significant org-culture related changes are incorporated into the standards, both economic and political drivers seem to foster the standardization of e-Commerce and other information system types [23]. A key to successful e-Commerce implementation has been found in topmanagement support [24].

Unlike in the private sector, the drivers of eGovernment initiatives seem to be mainly political rather than economical $[25,26,17,27]$. To some authors, Government-to-citizen (G2C) applications resemble customer-relationship management (CRM) systems, while government-to-business (G2B) applications remind of supply-chain management (SCM) systems in the private sector [28], see also [29]; furthermore, government-togovernment (G2G) applications appear to be similar to enterprise-resource planning (ERP) systems geared towards internal effectiveness and efficiency (IEE) (ibid). In fact, e-Government initiatives have led to comparable impacts like e-Commerce initiatives in the private sector, 
in that they have been found instrumental for increasing government-internal effectiveness and efficiency as well as external service levels and responsiveness [30, 26, 17]. Also, an increase in collaboration and particularly the sharing of knowledge and information has been observed in the course of e-Government initiatives [31], which, however, was influenced by a number of interacting factors such as context-embeddedness, practiceembeddedness, organization, and technology (ibid., also [32, 33]). Beyond the sharing of knowledge, interoperation of application and integration of information and processes have taken center stage in eGovernment [34-36] on national as well as on inter- and transnational levels [37]. Such initiatives seemingly need to be supported by adequate policy models [38]. Interestingly, the expectations regarding (desirable) effects and outcomes of e-Government seem to differ between government officials and citizens: while government officials are fairly confident about those effects and outcomes, citizens apparently are less sure but rather concerned about security and privacy as a study based on early data shows [39]. Like in the private sector, top management support has been found critically important for the success of e-Government initiatives [26].

In summary, the literature suggests similarities between e-Commerce and e-Government in areas such as (1) process improvements, (2) backend (process) integration, (3) cost savings, (4) information sharing, (5) vertical and horizontal e-systems integration, (6) increased responsiveness and service quality, (7) standardization efforts, and (8) the criticality of senior leadership support. Differences between the sectors seem to mainly prevail regarding (1) the drivers and motivations for e-Commerce and e-Government, (2) stakeholder expectations, and (3) resource availability. With this study we intend to enrich the understanding of these differences and similarities.

\section{Research Question and Methodology}

Study Questions. The two central study questions of this research are:

(1) What is similar in private-sector e-Commerce and public-sector e-Government, and how does it matter?

(2) What is different in private-sector e-Commerce and public-sector e-Government, and how does it matter?

Answering these two study questions would most probably help identify opportunities for cross-sector fertilization, which in turn might improve the sectorspecific approaches and initiatives. In the absence of any related comparative research antecedents and with a rather thin theoretical foundation relative to the study problem at hand, we decided that an exploratory research approach is in order [40-42].

Both e-Commerce and e-Government projects and implementations are engrained in institutional and social settings $[43,44]$ leading to a mesh of socio, technical, and organizational complexities, which defy the reduction of the study problem to a few variables. Under those conditions and accounting for the exploratory nature of the undertaking, we opted for the empirical format of focus group discussions, which has proven highly effective in such study situation [45-49], particularly, since the interaction between participants leads to rich data and high data quality [42].

Sampling Method. The sampling had to be purposive [50], since certain criteria outlined below had to be met in order to qualify for meaningful data. We also stratified the sample using Anthony's framework, which distinguishes between professionals, supervisors with operational control, managers, and strategic planners [51] and chose the managerial level for the pilot, since that level appeared to us high enough for capturing strategic aspects and motives as well as low enough to identify specifics of implementation and outcomes. Individuals were selected on the basis of willingness to participate and on the basis of prior involvement in and experience with e-Commerce or e-Government projects. For both sectors, participants were selected from organizations in the US Pacific Northwest, which has been found highly developed in both e-Commerce (for example, Amazon.com, Boeing, Microsoft, etc.) and e-Government $[52,53,16]$. We required that the projects, in which the participants had been involved, had been of strategic nature to the organization. Also, the project had to contain a major transactional component. In the private-sector focus group we ended up with six individuals from leading e-Commerce-engaged organizations representing various industries, while we had five individuals from the public sector representing the executive branch of various levels of government.

Data Collection. In the letter of invitation to prospective participants from the private sector, we verbally and graphically introduced the concepts of business-to-consumer (B2C), business-to-business (B2B), business-to-government (B2G), business-to-employee (B2E), and IEE. Likewise, we introduced the concepts of G2C, G2B, G2G, and government-to-employee (G2E) as well as IEE in the invitation letters to prospective participants from the public sector. Intentionally, we framed and pre-structured the discussion in that way for systematic comparability. We did not believe that this framing and pre-structuring would hamper the expert discussion in any way, on the contrary. For both groups we also introduced the two dimensions of "informational" and "transactional" for each of the above concepts. On 
two consecutive days we held half-day focus group discussions with the selected participants, first with the private sector participants, the next day with the public sector participants. The moderator first introduced the focus group format to the participants; she then reintroduced the e-Commerce and e-Government concepts as already outlined in the invitation letters. She explained to participants that the first session would be dedicated to the "informational" aspects of the five concepts followed by a second session on the "transactional' aspects. Prior to each session, participants were asked to prepare and write down discussion points for each concept as far as those applied to their projects and experience. The moderator then launched the focus group discussion with an opening question and facilitated the discussion, while three observers took notes and administered the audio recording [48]. The audio tracks were transcribed yielding over 170 pages of transcripts. Also, over 40 pages of notes were taken.

Data Analysis. In this study we mainly used Strauss and Corbin coding methodology [54]. In four passes, the transcripts and emerging concepts were analyzed. First, the two researchers independently read the transcripts identifying units of data. Our impression from the collection exercise was confirmed during this phase that we had in fact managed to collect rich and high-quality data in all four sessions. In the second pass, the two researchers read the transcripts again and consolidated the units of data. In an open coding process [54], each unit of data was then assigned to a preliminary category or subcategory whose dimensions and properties were developed from the data. New categories and subcategories were introduced, in case existing categories did not apply [55]. Convergence and assignment of categories, which the two researchers had identified independently, was performed at each step of the data analysis. In a subsequent pass, an axial coding process was applied, during which the converged categories/clusters and subcategories (emphasized in SMALL CAPITALS below) were analyzed regarding their inherent structures and processes leading to paradigms, whose internal relationships were identified wherever possible [54]. In the final pass, a selective coding process was performed, in which the resulting concepts and theories were related to each other. Surprisingly, the categories/clusters developed for e-Government by and large also emerged for the e-Commerce data analysis allowing for relatively straightforward linkage of the concepts found in the two sectors.

\section{Findings}

In this section, in which we present the results, we would like to begin with reminding the reader of the inherent constraints and limitation of our approach: We are seeking rich and qualitative data, which we hope helps us develop a deep and broad conceptual foundation of comparing e-Commerce and e-Government, which we can later subject to rigorous quantitative testing. None of these findings below have attached any claim of any generalizabilty. They are intended to serve as steppingstones in this theory-building effort.

Nine categories/clusters were developed from the coding process: (1) information management (2) process management (3) citizen/customer focus (4) digital divide (5) security (6) cost/benefit (7) stakeholders relations (8) standardization (9) resources. We will present the findings from both sectors alongside each other.

\subsection{Information Management}

Information management along with process management (next subsection) played a major role in the discussions of all four sessions. While the public sector participants highlighted the EASE OF USE of Web-based applications, which are simple and clear, as necessary prerequisite of usage, their private sector counterparts also pointed at USABILITY in terms of functionality. However, they remarked that users enjoy a fair amount of discretion regarding for what and how they use the system. WEBPAGE LIFE CYCLE MANAGEMENT and CONTENT MANAGEMENT were seen as major challenges in e-Commerce, which may severely impact the CREDIBILITY of information provided. If web content becomes obsolete or incorrect, the effects on the business could be very negative. Yet, maintaining content and structure of websites current has become a major resource and cost issue. For the e-Government side also government's LEGAL LIABILITY for the information provided was emphasized. In the public sector, it was said, the INFORMATION VOLUME had become very high through eGovernment, increasingly necessitating the development of a sound INFORMATION EXCHANGE strategy. Participants from both sectors emphasized the growing need for rethinking and restructuring the RECORD KEEPING, archiving, and document life management strategies. For private firms, also governments strictly regulated the archiving requirements for certain products, services, and contracts. ELECTRONIC DELIVERY MODES AND CHANNELS were a central theme in both groups; interestingly, while governments were concerned about those in terms of the digital divide, the private firms viewed them from the standpoint of effectiveness of communication. Both groups also mentioned the availability, accessibility, data minability, and the secure processing of PERSONAL INFORMATION and personalizable information as critical to success. If citizens and customers become wary of using the respective e-systems for the fear of disclosing an unacceptable degree of sensitive information, then the electronic system usage might drop it was said. On the other hand, citizens and customers value the availability 
of REAL-TIME INFORMATION, rich in FEATURES, tailored in content, and available 24/7, as a plus according to both groups. Again, both groups reported on the muchincreased volume of INFORMATION SHARING with other organizations, which yielded numerous benefits including cost savings and improved information quality.

\subsection{Process Management}

HigH TRANSACTION VOLUMES were reported as a much-welcomed result of e-Gov transaction projects. Government participants pointed at the cost savings per transaction, the economies of scale in both G2C and G2B contexts. This outcome was not explicitly mentioned but rather taken for granted in the private sector group. That group stressed the increased INTERNAL SERVICE requirements and also the high demand for ON-GOING SUPPORT along with high transaction volumes. Also, the more integrated supply-chain management (SCM) techniques and systems were used the more complexity had grown. The government group in turn emphasized that high-volume transaction processing had also required substantial upfront BUSINESS PROCESS REDESIGN. However, in some instances, processes were not redesigned but rather just web-enabled (MANUMATION, [56]) resulting in suboptimal outcomes. Both groups discussed the organization/contract SIZE factor in B2B and G2B. In their process- and interaction-related behavior, small and medium enterprises (SME) it was said resembled much more the B2C and G2C patterns and requirements than those of $\mathrm{B} 2 \mathrm{~B}$ and $\mathrm{G} 2 \mathrm{~B}$, which for some large private firms caused some concerns since SME would resent not being accepted as an equal partner to large companies under the B2B umbrella. Government participants were also concerned about the (lack of acceptable) PERFORMANCE of transactional EGIS, which might be related to the lack of process redesign. It appeared that private firms were much more highly integrated in terms of EXCHANGE OPERATIONS than government agencies, whose exchanges mainly pertained to information sharing. In e-Commerce, the SPEED OF TRANSACTION greatly mattered according to the discussants. Also, the TRACKING and the potential ROLLBACK OF TRANSACTIONS was seen as critically important in both groups, in terms of service quality and comfort to users. Furthermore, TRANSACTIONAL AVAILABILITY was expected on a 24/7 basis according to both groups, also with the capacity of facilitating RECURRING TRANSACTIONS. Government participants discussed that they had tried to learn from the BEST PRACTICES in e-Commerce when designing transactional EGIS (this was also said with respect to information management, standardization, and resource management). The private sector participants reported that their organizations favored a SWITCH FROM PUSH TO PULL mechanisms in transaction processing. Both groups noticed that the RELIABILITY of payment platforms in transactional processing was of the essence for all alternative methods offered. It was said that for ensuring compliance with GOVERNMENT REGULATIONS frequent audits occurred checking government contract-related eCommerce transactions.

\subsection{Citizen/Customer Focus}

In this cluster the main issues that were raised involved subjects of CITIZEN/CUSTOMER SATISFACTION, EXPECTATION MANAGEMENT, providing FULL SUPPORt and CITIZENS NEEDS.

The expectation according to previous literature on emphasizing the customer as the core of the business activity was found as improper [13]. Adversatively, the eGovernment highest reference was 'the citizen' and 'customer'. The differences between e-Government and e-Commerce were not only in terms of emphasizing the subject as a whole but also it terms of the way they captured the role of the customer/citizen in their realm. The e-Government focus group was referring to the citizen/customer as a partner. Putting a particular attention on understanding the citizen/customer needs, involve them in the decision-making processes, manage their expectation to leverage their satisfaction of the eGovernment services and promote usage and access of populations that might encounter difficulties. The main assumption that underlies the discussion was that PRIORITY OF CITIZENS trumps cost considerations. The eCommerce focus group treated the customer as a more passive actor. The perspective was more of a top-down, that is, what are the means by which a company should REACH a broader customer base, means to capture customer attention, define and implement the items that the customer needs to see and creating SPECIALIZED PORTALS fitting customer profiles. The interest in the customer needs mainly evolved around the desire for increasing revenue and benefit, giving companies a more proactive role in determining and defining the customer needs rather then involving customers in the business process definition. The paradox that evolved was that TRACKING CUSTOMERS/CITIZENS SATISFACTION had also an important role in the discussion, however mainly for the fear of complaints from customers or the fear of pullout of customers rather than trying to understand their needs. Government participants emphasized the crucial role of SERVICE ETHICS which was absent from the discussions of private sector participants.

\subsection{Digital Divide}

The cluster of digital divide was very minor in terms of weight it was given by e-Commerce focus group, while it served a big portion of the attention in their counterparts from the e-Government sector. Additionally, e-Government identifies challenges of ACCESS, REACH, LANGUAGE (TRANSLATION and localization), literacy, 
usage, infrastructure as digital divide and defines them as such. Whereas, e-Commerce were mainly referring to the concept in an indirect way through reaching a broader base of customers, having COMMUNICATION challenges between them and customers or internally, raising some translation issues and access management.

When referring to 'access management', while eGovernment treated this mainly with respect to the digital divide, e-Commerce reflected this term mainly through security aspects (see section 6.5). E-Government is interested to empower citizens in order to create a greater internal efficiency in their informational and business processes. Their service is intended to be delivered to the citizens. The public sector does not have the e-Commerce discretion and luxury to close a 'product' line because it is not beneficial, it rather has to provide certain services to all citizens/customers. The only discretion government has regards the methods and channels, by which they provide these services. This is why their major concerns is digital divide, allowing more people opportunities to use their services virtually.

\subsection{Security}

Security was one of the most prominent clusters that challenged e-Government - technical challenges (digital signature, encryption, authentication and critical systems), policy issues (regulations, security standards and ACCESS MANAGEMENT) and social issues (public safety, PRIVACY, INFORMATION DISCLOSURE AND TRUST). While the main concern raised by e-Government involved issues of national security rather than individual security, eCommerce did not give the subject that much weight. The challenges that e-Commerce brought up in terms of security mainly dealt with the individual level - that is how to make sure the privacy of customers is being kept. Concerns of e-Commerce are towards a negative impact over trust relations between the customer and the company. Particularly, e-Commerce is aware to its declining reputation due to cases of SHARING INFORMATION with governmental agencies and therefore a lot of effort is being given to building POLICY PROCEDURES to share personal information of customers with third parties and governmental agencies. Once again, like in the cluster of 'citizen/customer focus' the trigger to act is not due to privacy concerns but rather the fear to experience turn-over of customers and pullout.

\subsection{Cost and Benefits}

REDUCING COST was the main original driver for eCommerce as participants agreed. However, while the savings were reportedly substantial, other benefits also emerged over time among which REVENUE MAXIMIZATION, MORE CHOICES, CUSTOMER LOCK-IN, reduced SERVICE CALL FREQUENCY, and increased SELFSERVICE were most frequently mentioned. On the downside, some e-Commerce organizations encountered what they called the ROI PARADOX of e-Commerce, that is, continued investing in e-Commerce technology without getting a return. In those cases, some organizations seem to be driven to incur opportunity costs. Similarly, complaints were raised regarding unforeseen cost through vendor-FORCED SYSTEM UPGRADES and changes. Interestingly, the government group, although they also reported on cost reduction effects through e-Government, emphasized that the main motivation for implementing and using EGIS was the substantial improvement of internal and external service ("Better SERVICE TRUMPS COST!"). Government participants were also enthusiastic about numerous UNFORESEEN BENEFITS through EGIS such as improved interagency operations, increased quality of information, and higher levels of information sharing.

\subsection{Stakeholders Relations}

This cluster was raised strongly by both eGovernment and e-Commerce. E-Government grasped the success or failure of projects as contingent upon the cooperation of the various stakeholders and particularly the SUPPORT OR OBJECTION BY TOP-LEADERSHIP. eCommerce emphasized less the support of top-leadership and concentrated more on JUGGLING BETWEEN STAKEHOLDERS and balancing the various needs. Particular attention was given in the e-Commerce group to provide SYMMETRIC INFORMATION to the close communities (e.g., investors and employees) in order to avoid misunderstanding or potential frustration. As in the case of the cluster of 'citizen/customer focus' also here eGovernment paid more attention to involving stakeholders in the process as critical factor of implementing projects, while e-Commerce mainly concentrated in the procedural aspect of INTER-GROUP NETWORKING and relations between stakeholders. Both eGovernment and e-Commerce raised concerns regarding handling projects in DIFFERENT JURISDICTIONS.

\subsection{Standardization}

Standardization was of high level importance to both e-Commerce and e-Government. While e-Commerce emphasized more the security aspect of standardization, e-Government mainly paid attention to format and design issues. The INTEGRATION of various stakeholder information systems (mainly backend technology) was challenging. The reasons for concerns were different - eCommerce participants were concerned with integration, since their goal was to reach a SINGLE POINT ENTRY for customers that will work efficiently on all levels. However, e-Government participants were concerned with integration of information systems due to their commitment as a public sector to a high CONSISTENCY level towards citizens and customers. Additionally, government was challenged with standardization of presentation. Working with many vendors (e.g. electricity 
agencies, utility) and creating a level of standardization that sometimes contradict their desire to present their brand and uniqueness. This situation is less typical in the private sector.

\subsection{Resources}

The e-Commerce group reported that the DIGITIZATION of major archives had been completed over the years now reaping huge benefits in terms of resource reallocation and flexibility. Yet, even digitized archives and document repositories still require high levels of maintenance in terms of continuously required MIGRATION of documents from aging technology platforms to ever newer ones and to different TECHNOLOGY CHOICES. Increasingly, legacy systems were characterized as a burden rather than an asset due to resource-intensive high maintenance.

The resource intensity also led to the increased usage of commercial-off-the-shelf systems (COTS) and outsourcing of e-Commerce application. While the resource/cost problem can in part be addressed through the use of COTS and also VIRTUAL WORKPLACE approaches, an increase in COMPLEXITY with respect to external contractor management reduces the savings effect. In Government, the notorious SCARCITY OF RESOURCES and funds seemingly sparked investment in eGovernment, but also led to the same effect of OUTSOURCING and using COTS as in e-Commerce. The government participants emphasized that preserving and keeping human resources was of the essence, since the CUMULATIVE KNOWLEDGE and LONG EXPERIENCE had significantly contributed to the success of EGIS.

\section{Summary}

In table 1 below we summarize the main differences and similarities between the e-Government and eCommerce as found in our pilot.

\begin{tabular}{|l|l|l|}
\hline $\begin{array}{l}\text { Emphasis/ } \\
\text { Topics }\end{array}$ & $\begin{array}{l}\text { E-Commerce } \\
\text { Perspective }\end{array}$ & $\begin{array}{l}\text { E-Government } \\
\text { Perspective }\end{array}$ \\
\hline \multicolumn{3}{|c|}{ INFORMATION MANAGEMENT } \\
\hline $\begin{array}{l}\text { Ease of use } \\
\text { and usability }\end{array}$ & $\begin{array}{l}\text { Major factor of } \\
\text { success }\end{array}$ & Citizen-centric \\
\hline $\begin{array}{l}\text { Content } \\
\text { management }\end{array}$ & Major challenge - similar perspective \\
\hline $\begin{array}{l}\text { Information } \\
\text { volume }\end{array}$ & $\begin{array}{l}\text { High volumes of information } \\
\text { necessitating redesign information } \\
\text { exchange strategies and operation - } \\
\text { similar perspective }\end{array}$ \\
\hline $\begin{array}{l}\text { Record } \\
\text { keeping }\end{array}$ & $\begin{array}{l}\text { Focusing on } \\
\text { technical issues }\end{array}$ & $\begin{array}{l}\text { Emphasis on legal } \\
\text { liability }\end{array}$ \\
\hline Real-time & Feature-rich and tailored content available \\
\hline
\end{tabular}

\begin{tabular}{|c|c|c|}
\hline information & \multirow{2}{*}{\multicolumn{2}{|c|}{$\begin{array}{l}\text { 24/7 - similar perspective } \\
\text { PROCESS MANAGEMENT }\end{array}$}} \\
\hline PROCESS MANAGEMENT & & \\
\hline $\begin{array}{l}\text { Transaction } \\
\text { volumes }\end{array}$ & $\begin{array}{l}\text { Far higher and } \\
\text { therefore a need } \\
\text { for on-going } \\
\text { support }\end{array}$ & high \\
\hline $\begin{array}{l}\text { Business } \\
\text { process } \\
\text { redesign }\end{array}$ & More advanced & $\begin{array}{l}\text { Not as advanced, } \\
\text { still a lot of } \\
\text { manumation }\end{array}$ \\
\hline $\begin{array}{l}\text { Speed of } \\
\text { transaction }\end{array}$ & Essential & Non critical \\
\hline \multicolumn{3}{|c|}{ CITIZEN/CUSTOMER FOCUS } \\
\hline $\begin{array}{l}\text { Emphasis of } \\
\text { core } \\
\text { business }\end{array}$ & $\begin{array}{l}\text { Bottom-line } \\
\text { driven }\end{array}$ & $\begin{array}{l}\text { Citizen/customer- } \\
\text { centric }\end{array}$ \\
\hline $\begin{array}{l}\text { Treating } \\
\text { customers }\end{array}$ & $\begin{array}{l}\text { Top-down } \\
\text { perspective - } \\
\text { defining customer } \\
\text { needs }\end{array}$ & Involving customers \\
\hline $\begin{array}{l}\text { Service } \\
\text { ethics }\end{array}$ & No reference & Main challenge \\
\hline \multicolumn{3}{|c|}{ DIGITAL DIVIDE } \\
\hline $\begin{array}{l}\text { Emphasis of } \\
\text { cluster }\end{array}$ & $\begin{array}{l}\text { Almost no direct } \\
\text { reference to } \\
\text { digital divide. } \\
\text { Mainly translation } \\
\text { issues. }\end{array}$ & $\begin{array}{l}\text { Direct reference to } \\
\text { access, reach, } \\
\text { language, literacy, } \\
\text { content, usage and } \\
\text { infrastructure }\end{array}$ \\
\hline $\begin{array}{l}\text { Access } \\
\text { management }\end{array}$ & $\begin{array}{l}\text { Mainly in terms } \\
\text { of security or } \\
\text { reach of } \\
\text { customers }\end{array}$ & $\begin{array}{l}\text { In terms of } \\
\text { empowering } \\
\text { citizens/customers }\end{array}$ \\
\hline $\begin{array}{l}\text { Communicat } \\
\text { ion } \\
\text { challenges }\end{array}$ & Interpersonal & $\begin{array}{l}\text { Stakeholders } \\
\text { communication }\end{array}$ \\
\hline \multicolumn{3}{|c|}{ SECURITY } \\
\hline $\begin{array}{l}\text { Emphasis of } \\
\text { cluster }\end{array}$ & $\begin{array}{l}\text { Access } \\
\text { management and } \\
\text { authentication - } \\
\text { security is only } \\
\text { one subject }\end{array}$ & $\begin{array}{l}\text { Public safety, } \\
\text { national security } \\
\text { regulations, security } \\
\text { standards and } \\
\text { infrastructure - } \\
\text { security is a main } \\
\text { concern }\end{array}$ \\
\hline Privacy & $\begin{array}{l}\text { Avoid customer } \\
\text { retaliation }\end{array}$ & $\begin{array}{l}\text { Privacy in terms of } \\
\text { information } \\
\text { disclosure }\end{array}$ \\
\hline $\begin{array}{l}\text { Level of } \\
\text { attention }\end{array}$ & Individual level & National security \\
\hline Trust & \multicolumn{2}{|c|}{$\begin{array}{l}\text { Challenged by trust issues - similar } \\
\text { perspective }\end{array}$} \\
\hline \multicolumn{3}{|c|}{ COST/BENEFIT } \\
\hline $\begin{array}{l}\text { Emphasis of } \\
\text { cluster }\end{array}$ & Reducing cost & Improving service \\
\hline Benefits & Main goal & Unforeseen benefits \\
\hline \multicolumn{3}{|c|}{ STAKEHOLDERS RELATIONS } \\
\hline
\end{tabular}




\begin{tabular}{|l|l|l|}
\hline $\begin{array}{l}\text { Success/failu } \\
\text { re }\end{array}$ & $\begin{array}{l}\text { Juggling and } \\
\text { balancing } \\
\text { between } \\
\text { stakeholders }\end{array}$ & $\begin{array}{l}\text { Cooperation among } \\
\text { stakeholders. } \\
\text { Support of top- } \\
\text { leadership is } \\
\text { necessary }\end{array}$ \\
\hline relations & $\begin{array}{l}\text { Inter-group } \\
\text { networking }\end{array}$ & Alliances \\
\hline Jurisdiction & $\begin{array}{l}\text { Challenged by the need to work under } \\
\text { different jurisdictions }\end{array}$ \\
\hline \multicolumn{3}{|c|}{ STANDARDIZATION } \\
\hline $\begin{array}{l}\text { Emphasis of } \\
\text { cluster }\end{array}$ & Security & Format and design \\
\hline \multicolumn{3}{|c|}{ RESOURCES } \\
\hline $\begin{array}{l}\text { Availability } \\
\text { of resources }\end{array}$ & Resourceful & Resource scarce \\
\hline Outsourcing & High degrees & Highest degrees \\
\hline $\begin{array}{l}\text { Success/failu } \\
\text { re }\end{array}$ & No reference & $\begin{array}{l}\text { Accumulative } \\
\text { knowledge and } \\
\text { experience is critical }\end{array}$ \\
\hline
\end{tabular}

Table 1 - Differences and Similarities at a Glance

The literature review in section 4 suggests that similarities between e-Commerce and e-Government mainly occur in (1) process improvements, (2) backend (process) integration, (3) cost savings, (4) information sharing, (5) vertical and horizontal e-systems integration, (6) increased responsiveness and service quality, (7) standardization efforts, and (8) the criticality of senior leadership support. Differences between the sectors seem to mainly prevail regarding (1) the drivers and motivations for e-Commerce and e-Government, (2) stakeholder expectations, and (3) resource availability.

In this pilot, although conducted in a local US rather than global context, we empirically found that those concepts presented in the literature played major roles, however, it qualifies those differences and similarities of e-Government and e-Commerce by presenting a more refined and enriched picture. It also adds concepts, which so far were un- or underrepresented in the literature such as differences and similarities in information management, process management, responding to the digital divide, and cost/benefits.

\section{Conclusion and Future Research}

We intend to repeat the study with participants from other private and public sector organizations as well as other managerial and professional levels. We will then subject those results and insights from the first round of focus group interviews to scrutiny by joining interviewees from both sectors. More robust results are expected by employing this second-stage probing exercise. This will we believe lead to richer theoretical foundations, which we intend to subject to quantitative treatment.
Further comparative research on e-Commerce, on the one hand, and e-Government, on the other hand will we believe (a) improve the understanding of current practices and lessons learned in the two sectors, (b) have the potential for cross-fertilization between the sectors, (c) clarify the nature and origins of both similarities and differences between the evolutionary trajectories of the two phenomena, and (d) help evaluate the relative effectiveness and performance of e-Commerce and eGovernment.

\section{Acknowledgement}

We are indebted to our two graduate students Tim Carlson from the Master of Science in Information Management (MSIM) program and Deborah Turner from the doctoral program who helped us prepare for and conduct this research. Thanks so much!

\section{References}

[1] H. J. Scholl, "E-Government: A Special Case of Business Process Change," presented at 36th Hawaii International Conference on System Sciences (HICSS36), Waikoloa, HI, 2003.

[2] H. Rainey, R. Backoff, and C. Levine, "Comparing Public and Private Organizations," Public Administration Review, vol. 36, pp. 233244, 1976.

[3] G. A. Boyne, "Public and Private Management: What's the Difference?" Journal of Management Studies, vol. 39, pp. 97-122, 2002.

[4] B. Bozeman and S. Bretschneider, "Public Management Information Systems: Theory and Prescriptions," Public Administration Review, vol. 46, pp. 475-489, 1986.

[5] S. Bretschneider, "Management Information Systems in Public and Private Organization: An Empirical Test," Public Administration Review, vol. 50, pp. 536-545, 1990.

[6] L. Mohan and W. K. Holstein, "Eis: It Can Work in the Public Sector," MIS Quarterly, vol. 14, pp. 434-448, 1990.

[7] J. L. Perry and H. G. Rainey, "The PublicPrivate Distinction in Organization Theory: A Critique and Research Strategy," Academy of Management Review, vol. 13, pp. 182-201, 1988.

[8] M. Ward and S. Mitchell, "A Comparison of the Strategic Priorities of Public and Private Sector Information Resource Executives," Government Information Quarterly, vol. 21, pp. 284-304, 2004.

[9] H. J. Scholl, "Electronic Government: Information Management Capacity, Organizational Capabilities, and the Sourcing 
Mix," Government Information Quarterly, vol. 23, pp. 73-96, 2006.

[10] E. W. T. Ngai and F. K. T. Wat, "A Literature Review and Classificatiuon of Electronic Commerce Research," Information \& Management, vol. 39, pp. 415-429, 2002.

[11] A. Groenlund, "State of the Art in e-Gov Research: A Survey," presented at Third International Conference, EGOV 2004, Zaragoza, Spain, 2004.

[12] A. Groenlund, "State of the Art in e-Gov Research: Surveying Conference Publications," International Journal of Electronic Government Research, vol. 1, pp. 1-25, 2005.

[13] R. Amit and C. Zott, "Value Creation in eBusiness," Strategic Management Journal, vol. 22, pp. 493-520, 2001.

[14] M. E. Porter, "Strategy and the Internet," Harvard Business Review, vol. 79, pp. 63-78, 2001.

[15] L. Guijarro, "Analysis of the Interoperability Frameworks in e-Government Initiatives," in Electronic Government: Third International Conference, Egov 2004, Zaragoza, Spain, August 30-September 3, 2004. Proceedings, vol. 3183, Lecture notes in computer science, $\mathrm{R}$. Traunmüller, Ed. New York, NY: SpringerVerlag Berlin Heidelberg, 2004, pp. 36-39.

[16] C. H. Kaylor, "The Next Wave of eGovernment: The Challenges of Data Architecture," Bulletin of the American Society for Information Science and Technology, vol. 31, pp. 18-22, 2005.

[17] H. J. Scholl, "E-Government-Induced Business Process Change (BPC): An Empirical Study of Current Practices," International Journal of Electronic Government Research, vol. 1, pp. 2547, 2005.

[18] R. Traunmüller and M. A. Wimmer, "Integration: The Next Challenge in eGovernment," presented at EurAsia-ICT 2002, Shiraz, Iran, 2002.

[19] P. F. Johnson and R. D. Klassen, "EProcurement: Emerging Supply-Chain ETechnologies Provide Opportunities for Growthbut Reveal Pitfalls to Be Managed as Well," MIT Sloan Management Review, vol. 46, pp. 710, 2005.

[20] W. M. P. v. d. Aalst, "Inheritance of Interorganizational Workflows to Enable Business-to-Business e-Commerce," Electronic Commerce Research, vol. 2, pp. 195-231, 2002. [21] A. Andal-Ancion, P. A. Cartwright, and G. S. Yip, "The Digital Transformation of Traditional
Businesses," MIT Sloan Management Review, vol. 44, pp. 34-41, 2003.

[22] P. Anderson and E. Anderson, "The New ECommerce Intermediaries," MIT Sloan Management Review, vol. 43, pp. 53-62, 2002.

[23] M. Gerst, R. Bunduchi, and R. Williams, "Social Shaping and Standardization: A Case Study from the Auto Industry," presented at 39th Hawaii International Conference on System Sciences, Poipu, Kauai, HI, 2005.

[24] Y. Zhuang and A. L. Lederer, "The Impact of Top Management Commitment, Business Process Redesign, and It Planning on the Business-to-Consumer e-Commerce Site," Electronic Commerce Research, vol. 4, pp. 315333, 2004.

[25] D. H.-D. Lee, "Contextual It Business Value and Barriers: An E-Government and E-Business Perspective," presented at Proceedings of the 38th Annual Hawaii International Conference on System Sciences (HICSS'05) - Track 5, Island of Hawaii (Big Island), 2005.

[26] H. J. Scholl, "Motives, Strategic Approach, Objectives \& Focal Areas in e-Gov-Induced Change," International Journal of Electronic Government Research, vol. 1, pp. 58-77, 2005.

[27] L. L. Tung and O. Rieck, "Adoption of Electronic Government Services among Business Organizations in Singapore," The Journal of Strategic Information Systems, vol. 14, pp. 417-440, 2005.

[28] S. M. Lee, X. Tan, and S. Trimi, "Currrent Practices of Leading e-Government Countries," Commuications of the ACM, vol. 48, pp. 99104, 2005.

[29] N. C. Romano and R. Fjermestad, "Electronic Commerce Customer Relationship Management: A Research Agenda," Information Technology and Management, vol. 4, pp. 233-258, 2003.

[30] H. J. Scholl, "Organizational Transformation through e-Government: Myth or Reality?" presented at 4th International Conference EGOV05, Copenhagen, Denmark, 2005.

[31] J. Zhang, S. R. Faerman, and A. M. Cresswell, "The Effect of Organizational/Technological Factors and the Nature of Knowledge on Knowledge Sharing," presented at Proceedings of the 39th Annual Hawaii International Conference on System Sciences (HICSS'06) Track 6, Kauai, 2006.

[32] D. Wastell, P. Kawalek, P. Langmead-Jones, and R. Ormerod, "Information Systems and Partnership in Multi-Agency Networks: An Action Research Project in Crime Reduction," 
Information and organization, vol. 14, pp. 189210, 2004.

[33] K. A. Schildt, S. Beaumaster, and S. Bailey, "Organization Antecedents of Successful It Management," presented at Proceedings of the 39th Annual Hawaii International Conference on System Sciences (HICSS'06) - Track 6, Kauai, 2006.

[34] R. Klischewski, "Information Integration or Process Integration? How to Achieve Interoperability in Administration," in Electronic Government: Third International Conference, Egov 2004, Zaragoza, Spain, August 30September 3, 2004. Proceedings, vol. 3183, Lecture notes in computer science, $\mathrm{R}$. Traunmüller, Ed. New York, NY: Springer, 2004, pp. 57-65.

[35] R. Klischewski and H. J. Scholl, "Information Quality as a Common Ground for Key Players in e-Government Integration and Interoperability," presented at 39th Hawaii International Conference on System Sciences (HICSS39), Poipu/Kauai, HI, 2006.

[36] H. J. Scholl and R. Klischewski, "E-Government Integration and Interoperability: Framing the Research Agenda," International Journal of Public Administration, vol. 30, iss 2, in print, 2006.

[37] J. Roy, "E-Government and International Relations: A Consideration of Newly Emerging Capacities in a Multi-Level World," Journal of Electronic Commerce Research, vol. 6, pp. 4455, 2005.

[38] Z. Lan and S. Falcone, "Factors Influencing Internet Use - a Policy Model for Electronic Government Information Provision," Journal of Government Information, vol. 24, pp. 251-257, 1997.

[39] M. J. Moon and E. W. Welch, "Same Bed, Different Dreams? A Comparative Analysis of Citizen and Bureaucrat Perspectives on EGovernment," Review of Public Personnel Administration, vol. 25, pp. 243, 2005.

[40] S. Arthur and J. Nazroo, "Designing Fieldwork Strategies and Materials," in Qualitative Research Practice: A Guide for Social Science Students and Researchers, J. Ritchie and J. Lewis, Eds. London; Thousand Oaks, Calif.: Sage Publications, 2003, pp. 109-137.

[41] J. W. Creswell, Educational Research: Planning, Conducting, and Evaluating Quantitative and Qualitative Research, 2nd ed. Upper Saddle River, N.J.: Merrill, 2005.
M. Q. Patton, Qualitative Research and Evaluation Methods, 3 ed. Thousand Oaks, Calif.: Sage Publications, 2002.

G. DeSanctis and M. S. Poole, "Capturing the Complexity in Advanced Technology Use: Adaptive Structuration Theory," Organization Science, vol. 5, pp. 121-147, 1994.

W. J. Orlikowski and D. Robey, "Information Technology and the Structuring of Organizations," Information Systems Research, vol. 2, pp. 143-169, 1991.

H. Finch and J. Lewis, "Focus Groups," in Qualitative Research Practice: A Guide for Social Science Students and Researchers, J. Ritchie and J. Lewis, Eds. London; Thousand Oaks, Calif.: Sage Publications, 2003, pp. 170198.

T. L. Greenbaum, The Handbook for Focus Group Research, 2nd ed. Thousand Oaks, Calif.: Sage Publications, 1998.

T. L. Greenbaum, Moderating Focus Groups: A Practical Guide for Group Facilitation. Thousand Oaks, Calif.: Sage Publications, 2000.

R. A. Krueger and M. A. Casey, Focus Groups: A Practical Guide for Applied Research, 3rd ed. Thousand Oaks, Calif.: Sage Publications, 2000. E. Madriz, "Focus Groups in Feminist Research," in Handbook of Qualitative Research, N. K. Denzin and Y. S. Lincoln, Eds., 2nd ed. Thousand Oaks, Calif.: Sage Publications, 2000, pp. 835-850.

J. Ritchie, J. Lewis, and E. Gillian, "Designing and Selecting Samples," in Qualitative Research Practice: A Guide for Social Science Students and Researchers, J. Ritchie and J. Lewis, Eds. London; Thousand Oaks, Calif.: Sage Publications, 2003, pp. 77-108.

R. N. Anthony, Planning and Control Systems; a Framework for Analysis. Boston: Division of Research, Graduate School of Business Administration, Harvard University, 1965. A. T.-k. Ho, "Reinventing Local Governments and the E-Government Initiative," Public Administration Review, vol. 62, pp. 434-444, 2002.

C. Kaylor, R. Deshazo, and D. Van Eck, "Gauging E-Government: A Report on Implementing Services among American Cities," Government Information Quarterly, vol. 18, pp. 293-307, 2002.

A. L. Strauss and J. M. Corbin, Basics of Qualitative Research: Techniques and Procedures for Developing Grounded Theory, 2nd ed. Thousand Oaks: Sage Publications, 1998. 
[55] G. E. Gorman, P. Clayton, M. L. Rice-Lively, and L. Gorman, Qualitative Research for the Information Professional: A Practical Handbook. London: Library Association Publishing, 1997.

[56] W. K. Holstein and L. Mohan, "Management Imperatives: Forces That Will Shape Information Systems into the Next Century." Albany, 1998, pp. 60.

[57] W. H. DeLone and E. R. McLean, "Measuring eCommerce Success: Applying the DeLone \& McLean Information Systems Success Model," International Journal of Electronic Commerce, vol. 9, pp. 31-47, 2004.

[58] W. G. Bremser and Q. B. Chung, "A Framework for Performance Measurement in the E-Business Environment," Electronic Commerce Research and Applications, vol. 4, pp. 395-412, 2005. 